Intersections

Canadian Journal of Music

Revue canadienne de musique
Intersections CANADAN TOURAA OP NUSIC

\title{
Mark Laver. 2015. Jazz Sells: Music, Marketing, and Meaning. New York: Routledge. 246 pp. ISBN 978-1-138-01876-1
}

\section{Marco Katz Montiel}

Volume 35, numéro 2, 2015

URI : https://id.erudit.org/iderudit/1043825ar

DOI : https://doi.org/10.7202/1043825ar

Aller au sommaire du numéro

\section{Éditeur(s)}

Canadian University Music Society / Société de musique des universités canadiennes

ISSN

1911-0146 (imprimé)

1918-512X (numérique)

Découvrir la revue

Citer ce compte rendu

Katz Montiel, M. (2015). Compte rendu de [Mark Laver. 2015. Jazz Sells: Music, Marketing, and Meaning. New York: Routledge. 246 pp. ISBN

978-1-138-01876-1]. Intersections, 35(2), 131-135.

https://doi.org/10.7202/1043825ar

Copyright ( C Canadian University Music Society / Société de musique des universités canadiennes, 2018
Ce document est protégé par la loi sur le droit d'auteur. L'utilisation des services d'Érudit (y compris la reproduction) est assujettie à sa politique d'utilisation que vous pouvez consulter en ligne.

https://apropos.erudit.org/fr/usagers/politique-dutilisation/ 
Mark Laver. 2015. Jazz Sells: Music, Marketing, and Meaning. New York: Routledge. 246 pp. ISBN 978-1-138-01876-1.

Commercial music production moves rapidly. Endeavouring an understanding of the client's needs, often the most difficult part of the assignment, and perusing the final copy, which usually received approval from the legal department at the end of the day preceding the morning of the recording session, I would return home and work through the night creating a soundtrack that had no more conscious purpose than making the agency representatives and their clients grin from ear to ear. Most of the time this worked out well, and the payoff was fabulous; in addition to receiving upfront money and residual payments, at ten o'clock in the morning I got to hear my brief compositions performed by the finest musicians a corporate budget allowed.

Until reading Mark Laver's book, I never thought much about my choices of genre in advertising music or about the fact that so much of it had been jazz-or perhaps, more accurately, jazzy. As Laver observes, during much of broadcast history, jingles "used some jazz elements—a swing rhythm, a backup jazz band, a Modernaires-style vocal ensemble. This was largely because jazz was perceived to be a safe, broadly appealing, and uncontroversial (if slightly dated) popular music form" (p. 150). Jazz Sells: Music, Marketing, and Meaning convincingly explains how jazz, as a signifier and set of cultural practices as well as a body of music in a North American historical context, meets an especially wide variety of marketing requirements. While doing so, Laver's text pays close attention to a history of jazz as an African-American cultural practice that has effectively become, as Timothy Brennan points out in Secular Devotion: Afro-Latin Music and Imperial Jazz, the foundation of quotidian belief systems throughout North America and, indeed, much of the Western Hemisphere. This African-American history-and here we must acknowledge the hemispheric significance of that adjectival American-must be studied in conjunction with the consumer capitalism fueled by the slave trade and subsequent oppressive practices implicated in its unfolding.

Jazz musicians and their most historically attuned fans like to talk about how music can tell a story. Laver, as an alto saxophonist who has performed with Lee Konitz, Ali Berkok, and other improvising luminaries as well as with various symphony orchestras and wind ensembles, carries this storytelling ability over from his music to his use of the English language, a feat particularly impressive in a monograph designed for scholarly readers. This book pleases as much for its compelling insider tales from advertisers and musicians as for the nuanced layers of Cultural Studies and Philosophy it offers. Most usefully, it comes at readers sideways in order to implicate our academic world, certainly an important component of the demographic targeted by the sponsors 
discussed here, without making us feel directly attacked. If I had the power to compel my colleagues, notwithstanding their level of musical interest, to read one text this year, I would choose Laver's final section, "The Bank of Music," for its take on corporate sponsored festivals and the delusional sense of caring community they create.

Refreshingly, Jazz Sells contains ample Canadian content, even though this begins with a bit of national denial that should cease appearing in critical inquiries. "Race relations in Canada-where cultural diversity has long been a political and cultural touchstone, especially since the 1980s-are different from those in the United States," argues Laver (p. 33). Boasting undeniably crucial figures such as trumpeter Maynard Ferguson and pianists Gil Evans and Oscar Peterson, Canada can justifiably claim a significant share of jazz history, but it must also acknowledge its role in the not-always-pretty economic and political history that helped fuel the genre's rise in North America.

Plenty of Canadian authors have debunked such Canadian exceptionalism. In connection with the Africadian experience discussed here, uninformed readers would do well to check out George Elliott Clarke's "White Like Canada" and Afua Cooper's The Hanging of Angélique: the Untold Story of Canadian Slavery and the Burning of Old Montréal. Although CBC jazz hosts made much of Peterson's hardships while touring the southern United States, none mentioned the "shameful, disgusting, obscene harassment" of this jazz legend "by cowardly racist bigots" in Ontario that soured his final years (Stackhouse).

Laver more than makes up for this momentary lapse with well explicated applications of critical theory, from Adorno to Žižek along with a great deal of Feminist critique long overdue in studies of jazz, that steadfastly refuse to collapse into bifurcated social political representations. This does not turn Laver into a bloodless scholar, however; his nuanced observations acknowledge "the racism and sexism that continue to structure white supremacist patriarchy in North America and Western Europe" (p. 231) and how "most of us in the northwestern quadrant of the world have accepted the twin ideologies of capitalist plenty and limitless consumption, masking the real traumas of capitalism" (p. 232). While not groundbreaking in themselves, these thoughts, coming at the conclusion of a text that admits the views of sharply opposed musicians, economists, advertisers, bankers, and philosophers, make an unusually powerful impression.

Jazz Sells provides context for these thoughts with entertaining anecdotes and sometimes salty observations by workers in the advertising industry. His historical recollections include information that may be new to many readers. For example, "Cadillac dealers were forbidden to sell to African-American buyers until well into the 1940s" (p. 105). Laver does not miss the irony of this practice taking place in an environment in which automakers constantly employed jazz in order to promote their products. Also, "the world's first jazz festival seems to have been a small and woefully underdocumented event in Tallinn, the coastal capital city of Estonia, in 1948." This, Laver notes, took place some half a dozen years before its more famous counterpart in Newport, Rhode Island (p. 186). 
The connections between music and marketing lead Laver into useful discussions around the meaning of jazz, which he notes in the Preface, "has historically been a difficult genre of music to pin down" (p. xi). This ambiguity leads to the author's fundamental question: "what is it about jazz that has made it appealing to advertisers and marketers as an advertising and branding tool in these contexts and for these products?" (p. 2). In the world of advertising, jazz turns out to have multiple meanings that depend on the people or corporations making use of it. Some see the music occupying an interstitial space "uniquely situated on the cusp of the categories of 'art' and 'popular"' (p. 25), while Amiri Baraka views the term as a referent for "cultural practice" and George E. Lewis for "social location" (p. 26). In ad campaigns such as the one developed for Honda, jazz merely serves as a recognizable brand "in many different languages and cultures" (p. 114). Commercials for the car Honda named Jazz relied on a Russian folk song used for a popular Nintendo game and a theme resembling one used for the kid's show Thomas the Tank Engine. "Curiously," adds Laver, "despite the evident centrality of the jazz concept to the car's brand identity, and of the prominence of the word 'jazz' in all of the advertising and marketing messages about the car, jazz music is entirely absent" (p. 118, emphasis in Laver's text).

Even when it purportedly appears, not everyone agrees that it is indeed jazz. From Dinah Shore to Diana Krall, musical selections for so-called jazz soundtracks do not always fit easily into the genre. As one commercial composer tells Laver, people rarely request this type of music. "And you know, usually when they're asking for jazz, they of course don't really want, you know, what jazz lovers might consider jazz" (p. 157). This disconnect becomes pronounced in sections of the book dealing with sponsorships and the bankrolling of festivals by Toronto-Dominion (TD). Laver does a good job of laying out the benefits as well as perils of festival sponsorships. Amidst the latter, readers can easily pick out the dilution of jazz as a musical term; much of the popular content of these festivals comes from groups that no trained musician would associate with the genre.

Most of the problems with this book have more to do with publishing standards that plague many academic texts than with its authorship. These include the uneven quality of images, odd formatting choices, and issues with copyediting. Jazz Sells offers a few wonderful visual images, beginning with a cover photograph that, following the spirit of music and marketing, looks both jazzy and appealing. Inside the front cover, the book loses much of its visual appeal, with noticeably poorer reproductions of the images. This problem becomes dramatically pronounced in a series of barely legible cartoon stills from a Plymouth Valiant television advertising campaign (pp. 108-109). Formatting follies not only add extraneous pages, but also make a highly readable text more difficult to follow. Given that Laver has written a monograph rather than an anthology, bibliographies do not need to appear after each chapter. In addition to needlessly breaking into the text, some of these cited works resurface on multiple occasions. Unnecessarily detailed in-text citations also slow down the reading. Most distressing in an academic volume are the incorrect word 
choices, missing words, incorrectly added words, redundant phrasing, incomplete sentences, and plain old misspelling. There are few enough problems to indicate that the author knows how to write properly but enough to demonstrate that the publisher has not taken proper care of copyediting. Sadly, when funding constraints cause publishers to relinquish their responsibilities, scholarly writers will have to contract their own designers, layout specialists, and proofreaders.

In references to music, Laver handles technical terms well, bringing dominant seventh chords into play without having them dominate the text to the exclusion of musically unformed readers. Just as readers can appreciate the critical theory here without necessarily having studied every scholar cited, they can follow the music theory even in the absence of courses in solfege or form and analysis. Musical references receive support from the author's website, jazzsells.com, which, in addition to providing abstracts for chapter, links to videos of the commercials and other sonic examples discussed in the book. Taken together, the music, videos, and book provide an enjoyable as well as useful package.

Marco Katz Montiel

\section{WORKs Cited}

Brennan, Timothy. 2008. Secular Devotion: Afro-Latin Music and Imperial Jazz. New York: Verso.

Clark, George Elliott. “White Like Canada.” Transition. No. 73, 1997, pp. 98-109. Cooper, Afua. 2007. The Hanging of Angélique: The Untold Story of Canadian Slavery and the Burning of Old Montréal. Athens: University of Georgia Press.

Stackhouse, Reginald. "Racism and Oscar Peterson." Globe and Mail. 1 August 2006 http://www.theglobeandmail.com Viewed 15 April 2009.

\section{BIOGRAPHY}

Marco Katz Montiel teaches writing and literature at MacEwan University in Edmonton and as a Visiting Professor at the Pontificia Universidad Católica in Santiago de Chile. He also co-edits the Palgrave Studies in Music and Literature and, during the spring of 2018, has a research fellowship at the Franklin Institute of American Studies at the Universidad de Alcalá in Spain. His recent works include Las piedras del cielo, a CD released by Centaur Records, Music and Identity in Twentieth-Century Literature from Our America, a monograph published by Palgrave Macmillan, and the music chapter in the Wiley-Blackwell's A Companion to Popular Culture. As a freelance trombonist, Marco performed and recorded with well-known artists such as Vicki Carr, Cab Calloway, Trini López, Charlie Palmieri, La Orquesta Kubavana, and Steve Lawrence and Edie Gourmé. His recorded performances include In New Orleanswith Dan Andersen and Tubby the Tuba Play It Happy with Meredith Vieira, Paquito D'Rivera, and Jimmy Owens. Marco's compositions have been performed at Carnegie Hall, 
Avery Fischer Hall, and the Lincoln Center Library for the Performing Arts. He has also composed music for radio and television, including an award-winning soundtrack for Nickelodeon's Oh Yeah Cartoons. Bourne, Carl Fischer, International, Kendor, and Sneaky Yellow Dog Music publish his arrangements and compositions. 